УДК: 341.4/343.121.5

\title{
ВДОСКОНАЛЕННЯ СИСТЕМИ ВІДПРАВЛЕННЯ ПРАВОСУДДЯ ПО ВІДНОШЕННЮ ДО НЕПОВНОЛІТНІХ ЗА МІНІМАЛЬНИМИ СТАНДАРТНИМИ ПРАВИЛАМИ ООН («ПЕКІНСЬКІ ПРАВИЛА»)
}

\section{Широкова-Мурараш Ольга Геннадіївна}

кандидат історичних наук, доцент, Національний авіаційний університет, м. Київ, Київ ORCID: 0000-0002-8598-2853 skripshir@gmail.com

У статті аналізуються основні положення Мінімальних стандартних правил ООН, які стосуються відправлення правосуддя щодо неповнолітніх («Пекінські правила»)і стали відповіддю вчених та юристів-практиків з багатьох держав світу на загальну тенденцію росту підліткової злочинності.«Пекінські правила» ознаменували собою новий етап розвитку правосуддя для неповнолітніх. Зазначені правила розроблені з врахуванням різноманітності правових систем та суспільного розвитку держав і мають стати основою національних законодавств, що потребують реформування. А основні принципи, задекларовані у «Пекінських правилах», повинні відображатися у ювенальній політиці держав.

Проведений правовий аналіз дозволив виділити такі важливі принципи як забезпечення благополуччя неповнолітнього та соціальної справедливості; зменшення втручання з боку закону та гуманного поводження з підлітком, який знаходиться у конфлікті із законом; «принцип співмірності» (обмеження карних санкцій) та індивідуалізації відповідальності неповнолітніх осіб з урахуванням вчиненого діяння; принципи доцільного використання заходів впливу на неповнолітніх, обмеженого застосування покарань, заборони застосування смертної кари та тілесних покарань тощо.

Зроблено висновки, що вдосконалення системи відправлення правосуддя по відношенню до неповнолітніх згідно «Пекінських правил», перш за все, відповідає загальній тенденції гуманізації права та захисту прав дітей та підлітків, зокрема тих, що опинилися у конфлікті з законом. Їх імплементація у національне законодавство дає можливість розробити ювенальну політику держави, системи ювенального законодавства та ювенальної юстиції на основі сучасних міжнародно-правових стандартів, що у свою чергу, має сприяти 
підвищенню ефективності правового впливу та зниженню рівня підліткової злочинності.

Ключові слова: мінімальні стандартні правила ООН; правосуддя щодо неповнолітніх; пекінські правила; неповнолітні правопорушники; ювенальне право; ювенальна юстиція; кримінальна відповідальність неповнолітніх; права неповнолітніх правопорушників.

Shirokova-Murarash Olga, Ph. D. (Historical Science), Associate Professor, National Aviation University, Kyiv, Ukraine

\section{Improvement of the Juvenile Justice System under the Minimum UN Standard Rules (Beijing Rules)}

The article analyzes the basic provisions of the United Nations Minimum Standard Rules on the Administration of Juvenile Justice ("Beijing Rules") and responded to the worldwide trend of juvenile delinquency by scholars and practitioners from many countries around the world. These rules are designed to take into account the diversity of legal systems and the social development of states and should be the basis of national legislation in need of reform. In addition, the basic principles declared in the Beijing Rules should be reflected in the juvenile policy of the states.

The legal analysis made it possible to highlight such important principles as ensuring the welfare of a minor and social justice; Reduction of interference by law and fair and humane treatment of a teenager in conflict with the law; the "principle of proportionality" (limitation of punitive sanctions) and the individualization of the responsibility of minors, taking into account the act committed; expedient use of measures of influence on minors, limited use of punishments, prohibition of the death penalty and corporal punishment, etc.

It has been concluded that the improvement of the juvenile justice system under the Beijing Rules is primarily consistent with the general tendency to humanize the rights and protect the rights of children and adolescents, in particular those who are in conflict with the law. Their implementation into national law enables the development of juvenile policy of the state, the system of juvenile law and juvenile justice on the basis of modern international legal standards, which in turn should help to increase the effectiveness of legal influence and reduce the level of juvenile delinquency.

Key words: UN minimum standard rules; juvenile justice; Beijing rules; juvenile offenders; juvenile law; juvenile justice; juvenile criminal liability; juvenile offender rights. 

за мінімальними стандартними правилами ООН («Пекінські правила»)

Широкова-Мурараш Ольга Геннадьевна, кандидат исторических наук, доцент, Национальный авиационный университет, г. Киев, Украина

Совершенствование системы
несовершеннолетних в соответствии
правилами Оон («Пекинские правила»)

В статье анализируются основные положения Минимальных стандартных правил ООН, которые касаются отправления правосудия по отношению к несовершеннолетним («Пекинские правила») и стали реакцией ученых и юристов из многих стран мира на общую тенденцию роста подростковой преступности. «Пекинские правила» ознаменовали собой новый этап развития правосудия для несовершеннолетних. Разработанные с учетом разнообразия правовых систем и общественного развития государств, минимальные стандарты ООН должны стать фундаментом национальных законодательств, нуждающихся в реформировании. А основные принципы, задекларированные в «Пекинских правилах», должны отражаться в ювенальной политике государств.

Проведенный правовой анализ позволил выделить такие важные принципы как обеспечение благополучия несовершеннолетнего и социальной справедливости; уменьшение вмешательства со стороны закона; гуманного обращения с подростком, который находится в конфликте с законом; «принцип соразмерности» (ограничение уголовных санкций) и индивидуализации ответственности несовершеннолетних с учетом совершенного деяния; принципы целесообразного использования мер воздействия на несовершеннолетних, ограниченного применения наказаний, запрета применения смертной казни и телесных наказаний.

Сделаны выводы, что совершенствование системы правосудия в отношении несовершеннолетних согласно «Пекинским правилам» прежде всего соответствует общей тенденции гуманизации права, защиты прав детей и подростков, оказавшихся в конфликте с законом. Их имплементация в национальное законодательство дает возможность разработать ювенальную политику государства, системы ювенального законодательства и ювенальной юстиции на основе современных международно-правовых стандартов, что в свою очередь должно способствовать повышению эффективности правового воздействия и снижению уровня подростковой преступности.

Ключевые слова: минимальные стандартные правила ОOH; правосудия в отношении несовершеннолетних; пекинские правила; несовершеннолетние правонарушители; Ювенальное право; ювенальная юстиция; уголовная ответственность несовершеннолетних; права несовершеннолетних правонарушителей. 


\section{Вступ}

Захист прав дітей, що опинилися втягнутими у злочинну діяльність, напряму пов'язаний із вирішенням таких питань як покарання малолітніх правопорушників та поводження 3 ними. Тому перед міжнародним співтовариством постало завдання розробки та кодифікації таких спеціальних принципів та норм, які, по-перше, включали би права неповнолітніх правопорушників і зобов'язання держави стосовно відправлення правосуддя; а по-друге,могли бути відображені у національних законодавствах, враховуючи різноманітність правових систем та суспільного розвитку держав. Результатом міжнародного співробітництва стало прийняття низки міжнародно-правових джерел, що закріплювали стандарти ООН у галузі правосуддя і становили основу нової галузі права - ювенальної юстиції. Міжнародно-правовим актом, в якому були прописані мінімальні стандартні правила здійснення правосуддя по відношенню до малолітніх стали «Пекінські правила».

\section{Аналіз останніх досліджень і публікацій}

Питання відправлення правосуддя щодо неповнолітніх в сучасній українській юриспруденції висвітлюють О. І. Вінгловська, В. В. Вітвіцька, $\begin{array}{lll}\text { M. М. Гультай, } & \text { Н. М. Крестовська, } & \text { В. В. Лутковська, }\end{array}$ В. В. Романюкта ін. Тематика міжнародних стандартів і принципів у галузі покараньнеповнолітніх висвітлена у роботах Н. Л. Березовської, Є. С. Назімко, О. В. Романюка та В. О. Човгана.

Аналіз «Пекінских правил» як міжнародно-правового джерела здійснюється науковцями в межах зазначених робіт у комплексі із ін. міжнародно-правовими документами, тому, на нашу думку, цей міжнародноправовий акт, який визначив принципи поводження 3 неповнолітніми правопорушниками, потребує більш значної уваги.

\section{Формулювання мети і завдань статті}

Метою статті $\epsilon$ характеристика основних положень мінімальних стандартних правил ООН, які стосуються відправлення правосуддя щодо неповнолітніх («Пекінські правила») в світлі вимог ювенального права та ювенальної юстиції. Це дозволить виявити прогалини та досягнення в українському ювенальному законодавстві, вдосконалити систему покарань неповнолітніх на основі міжнародно-правових стандартів, враховуючи особливості та можливості економічного, політичного, правового та культурного розвитку українського суспільства, сприятиме ефективності правового впливу на особистість неповнолітнього правопорушника, профілактиці підліткової злочинності та зниженню їі рівня у суспільстві. 


\section{Виклад основного матеріалу дослідження}

Ускладнення соціального життя в умовах реформування правової системи, нестабільної політичної та економічної ситуації в Україні супроводжуються зростанням та молодшанням підліткової злочинності. У свою чергу, діти-правопорушники часто зіштовхуються 3 жорсткими вироками та засуджуються таким чином, що порушує їх права, а також принципи міжнародно-правового захисту прав дітей, які визнають позбавлення волі дітей лише в якості крайнього заходу. Належний захист прав дітей, профілактика підліткової злочинності та забезпечення умов виживання, розвитку та соціалізації дітей викликало створення нової галузі праваювенального права та відповідно ювенальної юстиції, які регулюють суспільні відносини за участю дитини, а також відносини, пов'язані зі створенням та функціонуванням ювенальних установ держави. Головним завдання ювенальної юстиції постає захист прав дітей шляхом створення системи органів, установ та організацій, які здійснюють правосуддя у справах про правопорушення, вчинені неповнолітніми. Разом із тим ювенальна юстиція передбачає програми реабілітації, консультування та відновного правосуддя.

Реалії сьогодення вказують на невтішну ситуацію: кожен десятий злочин вчинений неповнолітнім, які формують собою резерв для дорослого кримінального світу, в якому 50-60\% рецидивістів свої перші злочини вчинили не досягнувши повноліття(Mokrytska, 2005, p. 57). Діти стають на кримінальних шлях через неблагополучні соціальні умови та оточення. Парадоксальність ставлення до підлітків, що скоїли злочин, полягає в тому, що, з одного боку, надмірна суворість $є$ негуманна, а «зайва м'якість теж не йде на користь» (Mokrytska, 2005, p. 57). У такому випадку ювенальна юстиція, спираючись на сучасні тенденції, закріплені у міжнародно-правових джерелах, орієнтується на гуманне ставлення до підлітків. Такий підхід сформувався у процесі розвитку інституту захисту прав людини та діяльності 00Н.

Український дослідник В.В. Романюк стверджує, що першим кроком на шляху розвитку кримінального судочинства щодо неповнолітніх в Україні, у тому числі із врахуванням міжнародних стандартів відправлення правосуддя щодо дітей, повинно стати виявлення кола міжнародних правових актів з прав дитини, які в тому чи іншому аспекті регламентують їі права як учасника кримінальної процесуальної діяльності. Він підкреслює, що у відповідних міжнародних правових актах міститься система гарантій, забезпечення прав та законних інтересів дитини, яке повинно стосуватися не тільки прав та законних інтересів дитини у кримінальному судочинстві, а взагалі всього змісту її правового статусу як людини - найвищої соціальної цінності нашої держави (Romaniuk, 2019, p. 383). 
Під егідою ООН з 1955 р. один раз у п’ятиріччя проводяться конгреси із попередження злочинності i поводження 3 правопорушниками. На VII конгресі, Резолюцією 40/33 Генеральної Асамблеї ООН було затверджено мінімальні стандартні правила, які стосуються відправлення правосуддя щодо неповнолітніх. За рекомендацією Конгресу ООН, резолюція увійшла в світ під назвою «Пекінські правила» (надалі - Правила), які повинні були стати моделлю для держав-учасниць, чиї національні законодавства потребували перегляду та змін (Minimalnyie standartnyie pravila Organizatsii Ob'edinennyih Natsiy..., 1985). Цікаво, що Резолюція була прийнята у 1985 році, проголошеному ООН роком молоді.

У чому прогресивне значення та важливість прийнятого документу? По-перше, «Пекінські правила» входять у нормативно-правову базу ювенальної юстиції і становлять групу джерел, які мають рекомендаційний характер («м'яке міжнародне право») та відносяться до спеціальних міжнародноправових актів, які закріплюють положення щодо здійснення правосуддя до неповнолітних правопорушників (Berezovska, 2012, p.561). По-друге, задекларовані у Правилах міжнародно-правові стандарти повинні були стати моделлю для держав-учасниць, а їх положення сформульовані таким чином, щоб вони могли застосовуватися в рамках різних правових систем у контексті економічних, соціальних i культурних умов держав-учасниць. По-третє, Правила передбачали проведення всеохоплюючої соціальної політики, головний зміст якої становили заходи турботи про молодь, направлені на забезпечення благополуччя неповнолітніх, зведення до мінімуму необхідності втручання з боку системи правосуддя з метою зменшення шкоди, яка може бути заподіяна таким втручанням. По-четверте, Правила затверджували нові прогресивні положення і виступали за доцільне використання заходів впливу на неповнолітніх, обмежене застосування покарань, які передбачають позбавлення волі та ізоляцію неповнолітнього; перевага у такому випадку повинна віддаватися «відкритим» установам перед «закритими» і всі установи повинні бути виправного або освітнього, а не тюремного типу (Romaniuk, Chovhan, 2016, p. 128). I, нарешті, по-п'яте, саме з Пекінськими правилами пов'язуються уявлення про новий етап розвитку правосуддя для неповнолітніх.

Структура резолюції ООН 40/33 («Пекінські правила») складається з 6-ти частин, в яких сформульовано 30 правил із коментарями до них.

Частина перша «Загальні принципи» складається 3 правил, які розкривають роль соціальної політики, направленої на упередження злочинів та правопорушень з боку неповнолітніх шляхом створення умов для забезпечення змістовного життя підлітка в суспільстві, його благополуччя, зменшення втручання з боку закону та справедливого й гуманного поводження з підлітком, який знаходиться у конфлікті із законом(1.1-1.3). У цьому аспекті 
мова їде про ювенальну кримінальну політику держави, яка, на думку української дослідниці Н. М. Крестовської, є «стратегією державної діяльності у сфері протидії злочинності неповнолітніх та злочинам проти неповнолітніх, об'єктивована в системі нормативних актів та організаційних заходів, спрямованих на перевиховання та реінтеграцію неповнолітніх, які вчинили небезпечні діяння, охорона, захист та відновлення кримінально-правовими засобами прав та інтересів дитини» (Krestovska, 2008, p. 197). Правила наголошують, що правосуддя щодо неповнолітніх має стати складовою частиною процесу національного розвитку держави на основі забезпечення соціальної справедливості, захисту молоді та підтримки мирного порядку (1.4). Тому Правила перш за все, закріплюють такі основи державної ювенальної політики, які направлені на захист прав та інтересів дітей, зокрема тих, хто знаходиться у конфлікті з законом. Однією з ланок соціальної політики має стати вдосконалення системи правосуддя шляхом підвищення кваліфікації персоналу (1.6).

У Правилах уперше було конкретизовано поняття «неповнолітнього порушника», через визначення понять «неповнолітній» і «правопорушник» із урахуванням вимог існуючої правової системи. «Неповнолітнім правопорушником», згідно Правил, є дитина або молода особа (від 7 до 18 років або старше), що підозрюється у скоєнні правопорушення або що здійснила його(2.1-2.3). Слід зазначити, що вперше особа неповнолітнього правопорушника визначається у якості спеціального суб'єкта юридичної відповідальності у віковому діапазоні, який відображає мінімальні вікові межі в залежності від історичних і культурних особливостей тієї чи іншої держави (Romaniuk, Chovhan, 2016, p. 42).

У правилі 3 пропонується розширення сфери засобів захисту на три категорії осіб: неповнолітніх правопорушників, усіх неповнолітніх, по відношенню до яких застосовуються заходи соціального забезпечення та встановлюється опіка, а також на молодих повнолітніх правопорушників. Слід звернути увагу на те, що в коментарях до Правил, уточняється поняття «статусного злочину». Під яким мається на увазі, що коло дій, які розглядаються в якості правопорушень, ширше саме для неповнолітніх, ніж для дорослих (наприклад, прогули у школі, погана поведінка у школі та сім'ї та ін.).

У Правилах піднімається важливе питання встановлення віку, з якого особу може бути притягнуто до кримінальної відповідальності. Як зазначає $€$ С.Назімко воно $€$ напрочуд важливою складовою у справі визначення поняття «неповнолітнього» або «неповнолітнього правопорушника». Український дослідник зазначає, що міжнародний та європейський правовий стандарт не диктують чітких меж віку, з якого неповнолітні можуть бути 
притягнені до кримінальної відповідальності за вчинення кримінальнокараних діянь(Nazymko). Тому, відповідно до цієї традиції, у правилі 4 не прописується конкретний вік, а лише обумовлюється встановлення уміжнародному масштабі розумної нижчої вікової межі кримінальної відповідальності неповнолітніх, яка, згідно сучасному підходу, повинна враховувати рівень емоційної, духовної та інтелектуальної зрілості, здатність дитини перенести, пов'язані з кримінальною відповідальністю, моральні та психологічні аспекти.

Особливий наголос зроблено на двох найважливіших завданнях відправлення правосуддя: сприянні благополуччю неповнолітнього (метою $є$ можливість уникнення карних санкцій) та дотриманні «принципу співмірності» (обмеження карних санкцій, коли покарання має відповідати тяжкості правопорушення), який передбачає врахування індивідуальних особливостей правопорушника, жертви та обставин правопорушення(5).

Обсяг дискреційних повноважень у справах про неповнолітніх (6.1-6.3) закріплює практику врахування особливих потреб неповнолітніх при здійсненні цих дискреційних повноважень на всіх етапах судового розгляду та на різних рівнях відправлення правосуддя, у т. ч. при розслідуванні, розгляді справ у суді, винесенні судового рішення та здійсненні контролю за його виконанням. Разом із вимогою високої кваліфікації та підготовки осіб, які використовують ці повноваження, у Правилах здійснено, на думку російської дослідниці Е. Б. Мельникової, спробу подолати існуючий в теорії і практиці правосуддя конфлікт між розширенням і звуженням дискреційних судових повноважень у справах, що стосуються неповнолітніх (Melnykova, 2001, pp. 174-175).

Правило 7 розкриває обсяг прав неповнолітніх та у загальних рисах підтверджує основні процесуальні гарантії, до яких відносить: презумпцію невинуватості, право на повідомлення про звинувачення, право на відмову давати показання, право на адвоката, на присутність батьків або опікуна,право на апеляцію та інші, які визнані на міжнародному рівні у існуючих документах про права людини та мають бути гарантованими на усіх етапах здійснення правосуддя.

Правило 8 підкреслює важливість забезпечення права неповнолітнього на конфіденційність 3 метою його захисту від негативних наслідків опублікування та оприлюднення у засобах масової інформації матеріалів щодо їх справи. Саме тому в країнах, які дотримуються «Пекінських правил», повинен бути заборонений допуск представників преси, присутність публіки в залі, крім батьків або осіб, які їх заміняють, а за необхідності - й представників установ, які за дорученням суду вирішують питання щодо неповнолітніх. Положення про конфіденційність судового процесу необхідно дотримуватися, оскільки, 
як справедливо зауважує $\quad$ M. М. Гультай, існує концепція стигматизації («таврування») неповнолітнього обвинуваченого, підсудного «за допомогою» судового процесу, особливо відкритого, коли до постановлення вироку з'являються чутки, домисли, які ганьблять його ім'я, що може спричинити йому психічну травму і негативно позначитися на його долі (Gultai).

Друга частина Пекінських правил «Розслідування та судовий розгляд» найбільш деталізована. Правила 10.1-10.3 відображають загальні положення щодо ув'язнених за міжнародно-правовими стандартами, зокрема: повідомлення батьків або опікуна про затримання неповнолітнього, негайний розгляд справи, забезпечення усіма органами правопорядку поваги до правового статусу неповнолітнього та спричинення у ході судового процесі найменшої шкоди неповнолітньому (під шкодою розуміються, наприклад, грубі форми словесного звернення, фізичне насильство, осуд оточуючих), що передбачає співчуття та м'який, але вимогливий підхід.

Неодмінною умовою гуманізації процесу розслідування є застосування правила припинення справи неповнолітнього у досудовій стадії, яке можливе на будь-якому етапі прийняття рішення (11.1-11.4.). У Коментарях до Правил вказується, що припинення справи (преш за все, не пов'язаної із серйозними правопорушеннями) на самому початку може дати оптимальний результат. Будь-яке припинення справи неповнолітнього і передача його «общинним службам» вимагають згоди неповнолітнього або його законних представників (11.3).У правилі 11.4 рекомендуються ефективні альтернативи правосуддю по відношенню до неповнолітніх у вигляді реституції, здійснення тимчасового нагляду та керівництва.

Наскрізною у тексті Правил є ідея максимального скорочення обсягів застосування покарання у виді позбавлення волі. Правилами декларуються положення, згідно яких існуюча у досудовому розслідуванні практика утримання під вартою застосовується лише як крайній засіб протягом короткочасного періоду i, по можливості, замінюється іншими альтернативними заходами - постійним наглядом, активною виховною роботою, поміщенням у сім'ю чи виховний заклад або будинок (13.1-13.2). Продовженням цієї ідеї є положення, зазначене у статті 17, в якому говориться, що рішення про обмеження особистої волі неповнолітнього має прийматися тільки після ретельного розгляду питання і обмеження повинні бути зведені до мінімуму (17.1.б). Умовами для застосування обмеження волі в якості засобу впливу можуть бути визнання неповнолітнього винним у серйозному правопорушенні із застосуванням насилля проти особи,неодноразове здійснення інших серйозних правопорушень, а також відсутність інакшого відповідного засобу впливу (17.1.c). Відповідно до ст. 19.1, поміщення 
неповнолітнього у будь-яку виправну установу завжди має бути надзвичайним заходом, який застосовувався би у мінімально необхідні строки.

У третій частині «Винесення судового рішення та вибір засобів впливу» визначаються компетентні органи влади для винесення судового рішення: суд, трибунал, рада, комісія тощо (14.1). Суд повинен відповідати інтересам неповнолітнього і здійснюватися в атмосфері розуміння, що дозволить неповнолітньому брати в ньому участь та вільно висловлювати свою точку зору (14.2). Йдеться також про керівні принципи винесення судового розгляду та вибору заходів впливу: пропорційність заходів впливу не лише обставинам справи і тяжкості правопорушення, але й 3 положенням і потребами самого неповнолітнього (індивідуалізація відповідальності і покарання), а також з потребами суспільства.

Особливе застереження стосується заборони застосування смертної кари та тілесних покарань: «ні за який злочин, вчинений неповнолітнім, смертний вирок не виноситься» (17.2); «неповнолітні не піддаються тілесним покаранням» (17.3) i, як ми вже говорили вище, зведення до мінімуму обмеження особистої свободи неповнолітнього правопорушника (17.1).

Специфічною рисою ставлення до неповнолітніх, на відміну від дорослих, є право на припинення в будь-який момент судового розгляду (ст. 17.4). Слід звернути увагу на традиційне для кримінальної юстиції у справах неповнолітніх правило 18.1, у якому пропонується 8 груп заходів впливу, що успішно застосовуються в різних правових системах: керівництво та нагляд; пробація; компенсація і реституція; відшкодування збитку власною працею, робота на благо громади; групова терапія; ін. виховні заходи.

Як зазначається у Коментарях, мінімальні стандартні правила, які стосуються відправлення правосуддя у відношенні щодо неповнолітніх, вказують на підхід, що найбільше відповідає міжнародно визнаним принципам.

Особливістю четвертої частини «Поводження з правопорушниками поза виправними установами» (23-25) є те, що в ній акцентується увага на проведенні з неповнолітніми роботи, орієнтованої на перевиховання. Великого значення надається залученню у виховний процес громади як інструмент здійснення альтернативних рішень.

У п'ятій частині «Поводження 3 правопорушниками у виправних установах»(26-29) вказується, що у цьому випадку метою виховної роботи $є$ забезпечення опіки, захисту, освіти та професійної підготовки для надання їм допомоги із виконання суспільно корисної роботи, яка повинна сприяти реінтеграції неповнолітніх у життя суспільства. Разом із тим догляд, захист та необхідна соціальна, психологічна, медична та ін. форми допомоги мають здійснюватися із врахуванням вікових, статевих та індивідуальних особливостей (принцип індивідуалізації). Ці правила повинні бути прийнятні 
для будь-якої системи і культури. Нажаль, вони не були досягнуті повсюдно, тому держави мають провести значну роботу пов'язану з надання медичної та психологічної допомоги, яка має важливе значення для поміщених у виправні установи таких категорій осіб як наркомани, агресивні і психічно хворі молоді люди. Важливо зазначити застереження, за яким неповнолітні мають утримуватися окремо від дорослих (26.3).

Прописуючи правило 26.4, автори вирішили заповнити прогалину, пов'язану з тією обставиною, що жінкам-правопорушникам приділяється, зазвичай, менше уваги, ніж чоловікам. У ньому міститься заклик до справедливого та рівноправного ставлення щодо правопорушників жіночої статі 3 урахуванням їх особистих потреб і проблем на кожному етапі кримінального правосуддя.

Частина шоста «Дослідження, планування, розробка та оцінка політики» (30) вказує на необхідність створення механізму регулярних досліджень як основи раціональної політики у сфері відправлення правосуддя стосовно неповнолітніх з метою належної оцінки, вдосконалення та реформування цієі системи. 3 цією метою повинен проводитися комплексний і регулярний аналіз різноманітних конкретних потреб і проблем неповнолітніх та виявлення першочергових завдань.

Зауважимо, що «Пекінські правила» складені відповідно до сучасних підходів юридичної доктрини про неповнолітніх правопорушників і мають подвійну специфіку застосування у просторі як у рамках різних правових систем, так і як єдині мінімальні стандарти щодо відправлення правосуддя стосовно неповнолітніх.

Україна $є$ повноправним учасником низки міжнародних документів щодо захисту прав неповнолітніх правопорушників (Minimalnyie standartnyie pravila Organizatsii Ob'edinennyih Natsiy..., 1985). Тим самим Україна взяла на себе низку зобов'язань у сфері захисту неповнолітніх, що знайшли своє відображення в національному законодавстві і в умовах реалізації судовоправової реформи приступила до створення моделі ювенальної юстиції як комплексного механізму захисту неповнолітніх правопорушників.

У той же час Н. М. Крестовська зауважує на химерних уявленнях про ювенальну юстицію, що спричиняють критику та заважають ії розбудові. Наприклад, те, що ювенальна юстиція настроює дітей проти батьків (Krestovska, 2010). Але спростування цього міфу знаходимо у текстах міжнародно-правових джерел, присвячених захисту прав дитини, зокрема в «Пекінських правилах», де права батьків займають належне місце. У них зазначено, що:1) при затриманні неповнолітнього або його батьки або опікун негайно повідомляються про таке затримання, а у разі неможливості такого негайного повідомлення батьки або опікун повідомляються пізніше в 
найкоротші можливі строки (10.1); 2) віддання під нагляд сім'ї до судового розгляду вважається першочерговим запобіжним заходом (13.2); 3) батьки або опікуни мають право на присутність під час судового розгляду справи (15.2).

На прикладі України ми можемо побачити як працюють «Пекінські правила» в дії. Беручи за зразок перевиховання неповнолітніх у розвинутих країнах світу і керуючись «Пекінськими правилами», Міністерство юстиції України та Генеральна прокуратури України розробили та затвердили спільним наказом від 21 січня 2019 року № 172/5/10 пілотний проєкт «Програма відновлення неповнолітніх, які $\epsilon$ підозрюваними у вчиненні злочину». Ю. Луценко зазначив, що для ефективної реалізації Програми, в ній передбачається інформувати неповнолітнього, його законного представника та потерпілого шляхом залучення адвоката-медіатора регіонального центру з надання безоплатної вторинної правової допомоги та укладення угоди про застосування Програми відновлення; роз'яснити, що результати участі у Програмі враховуватимуться під час прийняття рішення про наявність підстав для звільнення від кримінальної відповідальності або закриття кримінального провадження. Також Генеральний Прокурор України зауважив, що позитивними наслідками впровадження програми буде: скорочення витрат бюджетних коштів на судовий розгляд; зменшення часу спілкування неповнолітнього з правоохоронними органами та судом, що не травмуватиме його психіку; потерпілий братиме участь у перевихованні неповнолітнього правопорушника та отримає відшкодування заподіяної йому шкоди; залучення громадських організацій та соціальних служб до роботи 3 неповнолітнім правопорушником для виправлення його поведінки, наповнення його дозвілля суспільно корисною діяльністю (Stvoreno proekt "Prohrama vidnovlennia nepovnolitnikh...).

Для реалізації пілотного проєкту визначені шість областей України: Донецька, Луганська, Львівська, Миколаївська, Одеська та Харківська. Його метою $є$ виведення неповнолітнього з кримінального провадження на ранніх стадіях, вжиття заходів його ресоціалізації та запобігання повторному вчиненню злочинів.

Цікавим прикладом виконання пілотного проєкту в Харківській обл. $\epsilon$ випадок із 16-річним Ш. Підлітки викрали два паркові гучномовці, перебуваючи на території Центрального парку культури та відпочинку ім. М. Горького. Після повідомлення про підозру у вчиненні кримінального правопорушення середньої тяжкості, інформування та отримання прокурором усної згоди від сторін, за участю адвоката-медіатора було укладено угоду про застосування Програми відновлення для неповнолітніх, які є підозрюваними у вчиненні злочину. Згідно 3 угодою підозрюваний разом із повним відшкодуванням завданої шкоди зобов'язався протягом двох тижнів, у вільний 
від навчання час, прибирати листя, білити дерева, допомагати під час інших заходів із підтримання порядку та облагороджування парку. Таким чином було визначено, що саме робота з благоустрою парку, буде найкращим засобом перевиховання неповнолітнього правопорушника (Stepanova, 2019).

Ця Програма свідчить про втілення Україною основних положень «Пекінських правил» у своїй соціальній політиці, що дає надію на зменшення кількості неповнолітніх, направлених для перевиховання до місць позбавлення волі, найскорішу їх ресоціалізацію у суспільне життя нашої країни.

\section{Висновки}

«Пекінські правила» стали відповіддю вчених та юристів-практиків 3 багатьох держав світу на загальну тенденцію росту кількості неповнолітніх правопорушників і ознаменували собою новий етап розвитку правосуддя для неповнолітніх. Саме «Пекінські правила» конкретизували поняття «неповнолітній правопорушник», «статусне правопорушення», «розумної нижчої вікової межі кримінальної відповідальності неповнолітніх» та закріпили важливі принципи щодо застосування покарання до неповнолітних, на яких повинна будуватися політика ювенальної юстиції держав, зокрема: забезпечення благополуччя неповнолітнього та соціальної справедливості; зменшення втручання з боку закону та справедливого й гуманного поводження з підлітком, який знаходиться у конфлікті із законом;«принцип співмірності» (обмеження карних санкцій) та індивідуалізації відповідальності неповнолітніх осіб з урахуванням вчиненого діяння; доцільного використання заходів впливу на неповнолітніх, обмеженого застосування покарань,заборони застосування смертної кари та тілесних покарань тощо.

Головними положеннями мінімальних стандартних правил ООН щодо відправлення правосуддя стосовно неповнолітніх $\epsilon$ максимальне обмеження застосування покарань, пов'язаних з позбавленням волі (лише як надзвичайна міра) та, навпаки, розширення сфери застосування альтернативних засобів впливу, надання переваги при відбуванні покарання малолітніми злочинцями установам «відкритого» типу, ніж «закритого», характер діяльності виправних установ має бути виховний та освітній, а не каральний.

Таким чином, міжнародні та європейські стандарти застосування покарання до неповнолітніх, закріплені у «Пекінських правилах»,відображають тенденцію до гуманізації системи правового впливу з метою перевиховання та захисту прав і свобод неповнолітнього правопорушника, знижуючи у цілому рівень злочинності в суспільстві. 


\section{References:}

1. Berezovska, N. L. (2012). Mizhnarodne spivrobitnytstvo u sferi pokarannia nepovnolitnikh [International cooperation in the field of juvenile punishment]. Aktualni problemy derzhavy i prava [Current Problems of State and Law], issue 65, pp. 559-567. Available at: http://nbuv.gov.ua/UJRN/apdp_2012_65_77.

2. Gultai, M. M. Osoblyvosti vitchyznianoi modeli yuvenalnoi yustytsii[Features of the domestic model of juvenile justice]. Verkhovnyi Sud Ukrainy [The Supreme Court of Ukraine], [online]. Availiable at: URL: http://www.viaduk.net/clients/vs.nsf/0/FD13963E350840C5C225710100399CD1.

3. Krestovska, N. M. (2008). Yuvenalne pravo Ukrainy: istoryko-teoretychne doslidzhennia [Juvenile law of Ukraine: historical and theoretical study]. Odesa: Feniks.

4. Krestovska, N. M. (2010). Mify pro yuvenalnu yustytsiiu [Myths about juvenile justice]. Viche, no. 15, [online]. Available at: http://veche.kiev.ua/journal/2126/.

5. Melnykova, E. V. (2001). Yuvenalnaia yustitsiia: Problemy ugolovnogo prava, ugolovnogo protsessa v kriminologii [Juvenile Justice: Problems of Criminal Law, Criminal Procedure and Criminology:] Moscow: Delo.

6. Minimalnyie standartnyie pravila Organizatsii Ob'edinennyih Natsiy, kasayuschiesya otpravleniya pravosudiya $v$ otnoshenii nesovershennoletnih (Pekinskie pravila): Rezolyutsiya 40/33 Generalnoy Assamblei OON ot 29 noyabrya 1985 g. [United Nations Minimum Standard Rules on the Administration of Juvenile Justice (Beijing Rules): United Nations General Assembly Resolution 40/33 of 29 November 1985], [online]. Available at: http://www.un.org/ru/documents/decl_conv/conventions/beijing_rules.shtml.

7. Mokrytska, I. Ya. (2005). Yuvenalna yustytsiia: pravovyizakhyst ditei [Juvenile Justice: Legal Protection of Children]. Naukovi zapysky. Yurydychni nauky [Scientific Notes. Legal sciences], [online]. Available at: http://ekmair.ukma.edu.ua/bitstream/handle/123456789/8049/Mokrytska_Yuvena lna_yustytsiia.pdf?sequence=1\&isAllowed=y.

8. Nazymko, Ye.S. Zmistovni skladovi mizhnarodnykh ta yevropeiskykh standartiv zastosuvannia pokarannia do nepovnolitnikh [Substantive components of international and European standards for the use of juvenile punishment], [online]. Available

at: https://www.dli.donetsk.ua/index.php?option=com_content\&view=article\&id=3937.

9. Romaniuk, O.V., Chovhan, V. O. eds. (2016). Mizhnarodni standarty, pryntsypy i rekomendatsii $v$ haluzi vykonannia pokaran ta diialnosti orhaniv $i$ ustanov vykonannia pokaran: metodychni rekomendatsii [International Standards, Principles and Recommendations in the Field of Sentencing and the Activities of Sentencing Bodies and Institutions: Guidelines]. Bila Tserkva. 
10. Romaniuk, V. V. (2019). Znachennia mizhnarodno normatyvno-pravovykh aktiv dlia podalshoho rozvytku kryminalnoho provadzhennia shchodo nepovnolitnikh [The importance of international legal acts for the further development of criminal proceedings against minors]. Miskolc, Hungary.

11. Stepanova, A. Pilotnyi proekt Prohramy vidnovlennia dlia nepovnolitnikh, yaki ye pidozriuvanymy u vchynenni zlochynu, - v dii [Pilot Project on Juvenile Suspect Recovery Program in Action], [online]. Available at: https://khar.gp.gov.ua/ua/intervu_ta_komentari?_m=publications\&_t=rec\&id=25471 5.

12. Stvoreno proekt "Prohrama vidnovlennia nepovnolitnikh, yaki ye pidozriuvanymy u vchynenni zlochynu" [The project "A program for the recovery of juveniles suspected of committing a crime"], [online]. Available at: https://galinfo.com.ua/news/stvoreno_proekt_programa_vidnovlennya_nepovnolitni h_yaki_ie_pidozryuvanymy_u_vchynenni_zlochynu_306147.html.

(C) Широкова-Мурараш О. Г., 2020 